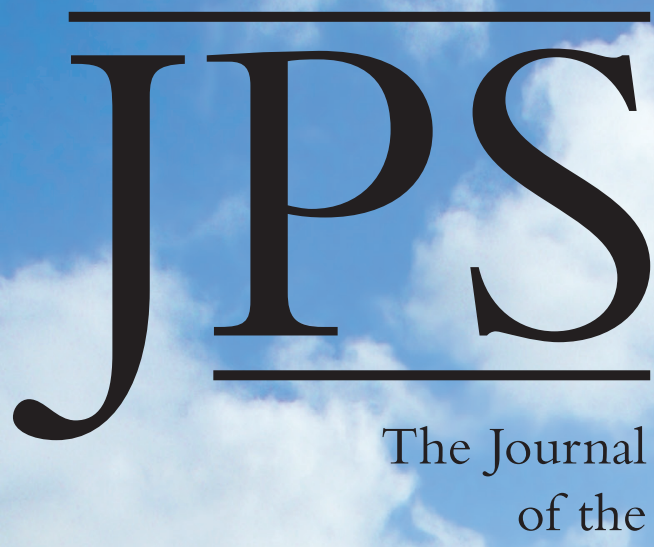

Polynesian Society

VOLUME 125 No.4 DECEMBER 2016

THE POLYNESIAN SOCIETY

1.t. THE UNIVERSITY OF AUCKLAND NEW ZEALAND

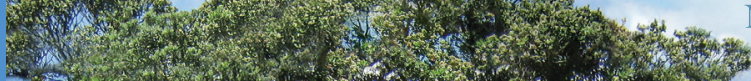

1.2.

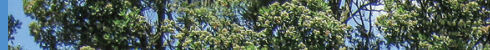

(2)

F.t.

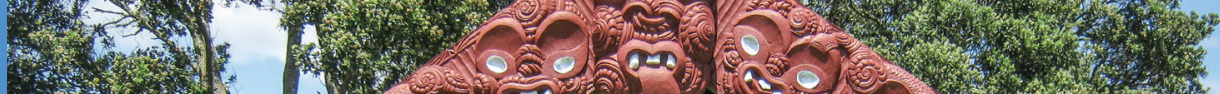

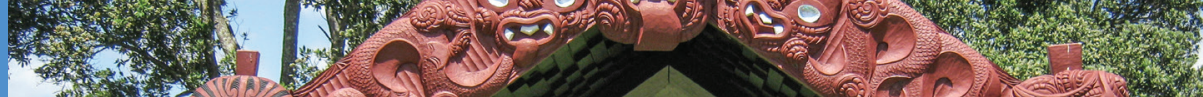

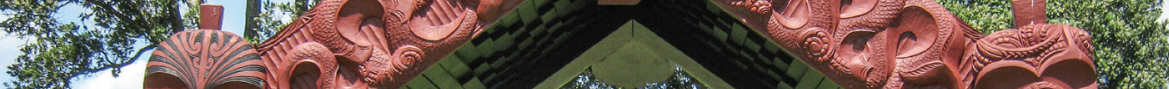

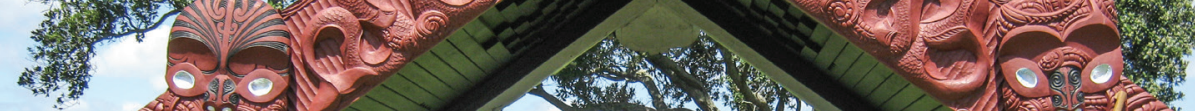

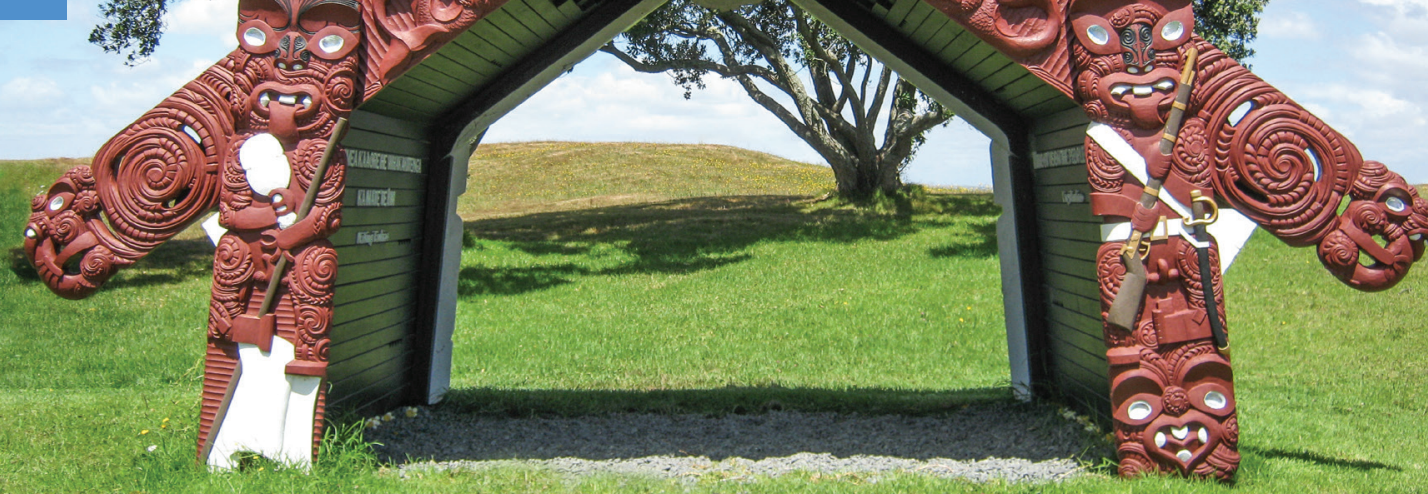




\title{
INDIGENOUS ENTREPRENEURSHIP: CULTURAL CODING AND THE TRANSFORMATION OF NGĀTI WHĀTUA IN NEW ZEALAND
}

\author{
MERATA KAWHARU \\ University of Auckland \\ University of Otago
}

"What do you make of this, partner?"

The opening quote was the message of the Ngāti Whātua hapū or 'kin community' leader to the New Zealand Government as he and his team sat down with Crown representatives during the late 1990s-2000s to discuss and to settle the community's outstanding Treaty of Waitangi claim. ${ }^{1}$ The Ngāti Whātua claim concerned what was in essence the loss of their ancestral land that now encapsulates the Auckland urban sprawl. The area covered much of the central, northern and western parts of New Zealand's largest city. Its significance is conveyed by ancient names of the wider area, including Tamaki Makaurau 'Tamaki desired by hundreds', Tamaki Herenga Waka 'Tamaki the place where canoes are tied', Tamaki Kainga Ika me Nga Wheua Katoa 'Tamaki where fish and bones are so succulent that they are all consumed'. Historically then, as these names indicate, it is clear that Tamaki had a great deal to offer. In addition to the Treaty claim, other major initiatives in Tamaki have taken shape over the past 20 years as Ngāti Whātua sought to re-establish their interests in the region. These have led towards major socio-economic transformation for the kin community. They have also required astute leadership and a re-kindling of a partnership with the Crown, despite the history that saw a total breakdown of this relationship. One enterprise in particular has involved entrepreneurial "edge", including having considerable ingenuity, pushing boundaries and having some degree of risk-taking. There was much at stake, all of which hinged on reinvigorating the community's identity in the eyes of its descendants and the wider public. Now, the small community's transformation is starting to take shape. The Treaty claim has been settled. Cultural regeneration is occurring. Much is yet to be undertaken economically and culturally, but there is much to learn from the last 15 to 20 years.

This article traces this recent past. It focuses on one particular journey in the 1990s to acquire a large area of Auckland central business district land, formerly railway land. The community's relatively sudden propulsion into major economic advancement that started with the purchase and development 
of this land has been given much attention by mainstream media. Beyond the headlines and public commentary though are deeper issues concerning the opportunities taken or lost, and the outcomes that have arisen despite setbacks or constraints. I examine closely the leadership behind the Ngāti Whātua Railway Land initiative, the actions taken, the lessons learned and the implications that these events have had for the community's identity, place and future. While these things by themselves are worthy of telling, the story is also one from which broader theories of indigenous entrepreneurship can be considered. ${ }^{2}$

To situate the enterprise, I discuss current indigenous entrepreneurship literature, the place of Māori entrepreneurship within that broader context, and the gap or the opportunity to examine culture in entrepreneurship more specifically. I then turn to exploring the idea of "cultural coding for entrepreneurship" and what that means in the case study context. I briefly consider methodological approaches to the research for this article to help frame the discussion of events that then follows in the remainder of the article.

\section{INDIGENOUS ENTREPRENEURSHIP}

Māori entrepreneurial endeavour stems back some 20 or more generations ago to their ancestors who traversed the 3000-plus km expanse of the Pacific Ocean from Tahiti or Rarotonga to New Zealand (Tapsell 2014). Excursions also occurred between East Polynesia, New Zealand and South America. This entrepreneurial spirit continued as the first inhabitants to New Zealand explored and adapted to new lands (Anderson et al. 2015, Buck 1950, Firth 1972, Tapsell 2014, Walker 1990). It took on new forms generations later when they engaged in new international and domestic markets in the early decades of the 19th century with non-Māori settlers (Petrie 2006), through harvesting flax, providing kauri (Agathis australis) tree trunks as spars for ships, or running their own schooners or flour mills. In contemporary times, entrepreneurship is different again as Māori respond to and create new social or economic opportunities, either at home within community contexts, in cities away from customary territories or even internationally. Recipients of enterprises may be community-wide or they may derive from within smaller family contexts (Mahuika 1992). Yet despite the flourishing of entrepreneurship by Māori groups and individuals and their ancestral precedents, little theoretical development has occurred except in recent years. Those contributing theoretical insights include Frederick and Henry (2004), Henry (2007), Kawharu et al. (2012) and Tapsell and Woods (2008a, 2008b, 2010).

Māori entrepreneurship can be seen as a branch of indigenous entrepreneurship, where "indigenous" broadly relates to people who self-identify as 
the first or original inhabitants. Although there is no one simple definition of indigenous people given the diversity and richness of experiences worldwide, the United Nations' broad understanding of indigenous people is helpful. The UN describes indigenous peoples as those who have "historical continuity with pre-colonial and/or pre-settler societies, [a] strong link to territories and surrounding natural resources, distinct social, economic or political systems, distinct language, culture and beliefs, [and they often, but not always] form non-dominant groups of society" (United Nations n.d). The International Labour Organisation (ILO) has a similar view: "Indigenous and tribal peoples have their own cultures, languages, customs and institutions, which distinguish them from other parts of the societies in which they find themselves." (ILO n.d.).

Entrepreneurship within indigenous contexts, an emerging field of inquiry, is equally difficult to define given the multiple experiences and interpretations of "being" indigenous, and the wide boundaries of investigation. Issues explored include, for example, purposes of indigenous entrepreneurship, which aim towards nation-building (Anderson and Giberson 2004) or self-development "by and for indigenous people" in response to histories of colonisation and/ or deprivation where indigenous peoples are agents of change (Anderson et al. 2004a, 2004b, Dana 2007, Dana and Anderson 2007, Henry 2007, Hindle and Lansdowne 2005). Indigenous entrepreneurship is understood by some to operate at the intersection of social and economic entrepreneurship (Anderson et al. 2006, Tapsell and Woods 2008a). Henry (2007: 542) agrees, adding that for Māori, entrepreneurship is "underpinned by social objectives to improve wealth and well-being for the community, rather than just the individual". Kawharu (2014) and Robinson (2014) add to this general line of thinking in respect of Māori communities where economic aspirations in business enterprise function as means towards ends that are actually intrinsically about socio-cultural and economic well-being or enhancement. Other indigenous peoples appear to share similar integrated, socio-economic, including cultural, aspirations as well (Dana and Anderson 2007).

An opportunity for indigenous entrepreneurship more generally, and for Māori entrepreneurship theories in particular, is to explore the nuances of culture, which are currently not well understood (Kawharu et al. 2012, Lindsay 2005). In addressing this gap, Hindle and Lansdowne (2005) offer insights where, for example, "culture" is central to entrepreneurship via: the heritage positioning index, the autonomy-accountability network (where autonomy distinguishes one venture from another and where the venture must be accountable to multiple groups), and the twin skills inventory (where technical and cultural skills are both vital). These are important facets in the Ngāti Whātua innovation in respect of the mix of skills of the leaders, their 
cultural values, and the leaders' accountability back to the kin community. Frederick and Henry (2004), Kawharu et al. (2012) and Tapsell and Woods (2008a, 2008b) discuss culture in entrepreneurship in two further important ways in New Zealand. One is to consider culture in its historical context as an important guide for current innovation. And the second is to view culture as expressed in complementary leadership roles, roles which work together towards the identification and realisation of innovation (Kawharu et al. 2012, Tapsell and Woods 2008a, 2008b).

Building on these insights, the idea of "cultural coding" can be used as a frame to identify and explain standout variables for entrepreneurial endeavour within Ngāti Whātua. As alluded to above, the first point is the primacy of history for coding why the entrepreneurship should take shape. Ngāti Whātua's story is about transformative events of recent times, but it is also a story deeply embedded in their past. As discussed further below, their history of virtually complete land loss over a 120 -year period, a process which began in the 1840s and continued until 1951. Their resilience as a community in the face of this loss are central planks for guiding the kind of entrepreneurial outcomes that they sought. History uncovers an inter-related web of events and leadership, which in turn provide guiding markers to later generations for what was important, what should be done and how. Their past essentially describes how the community maintained their survival in the face of challenge, crisis or adversity or in the face of opportunity, and how in the process they maintained access to economic, political or social resources. The actions of Ngāti Whātua leaders over generations in postEuropean contact times centred on the desire to secure, or more accurately, resurrect their community's connection and title to ancestral land, land which was and is their source of cultural, economic and political well-being, status and identity (I.H. Kawharu 1975, 1989, M. Kawharu 2004, Waitangi Tribunal 1987). Put into context and into a contemporary view, their whakapapa 'genealogical past' covering these key motivations provides the basis or a "ground up" perspective that ensures that development or innovation fits their circumstances and values.

Related to these ideas, cultural coding for entrepreneurship also extends to values within the kinship system. Three were of particular importance to Ngāti Whātua: mana, manaaki and kotahitanga. Mana, interpreted to mean authority and strength, was evident when the Ngāti Whātua members and their strategic advisors voiced fervent perspectives to an intransigent, but ultimately changing, Crown position about land price and partnership. Mana applied to each of the key leaders involved in this story. Each were strong, powerful and persuasive advocates in their own unique ways in arguing or presenting a specifically Ngāti Whātua perspective to private sector agents 
and commercial entities as well. But mana was also about the hapu regaining their foothold or presence in their ancestral landscape. And it was about their leaders leading initiatives with the outcomes of strengthening hapu identity and confidence in the eyes of the kin community, the wider Māori world, the civic community and wider New Zealand. The national-level perspective was an important one given the recent history of Ngāti Whātua and the nationally-significant Bastion Point protest, occupation and campaign, as will be discussed below.

Manaaki, meaning to care for or to consider others, is the complementary cultural value or counterpart to mana. While mana is concerned with rights or what can be gained, manaaki is essentially about duties or what can be given. Manaaki was a key cultural element that coded the kin community's entrepreneurial success. It applied to each of the leaders in terms of their respect for one another. It also applied to the leadership group as a team, in relation to the kin community. After all, it was the community, that is, the living and those yet to be born, for whom they were bothering to take risks, to go out on a limb, and to create something socially and economically visionary for inter-generational benefit. To put it simply, cultural coding for entrepreneurship within the Ngāti Whātua context was very clearly driven by the mana/manaaki dynamic.

Kotahitanga, or unity, I apply to the idea "kotahitanga of difference", which principally refers to the complementary, but different, customarybased leadership values and roles that operated within the Ngāti Whātua innovation context. These included rangatira 'chiefly leaders' who are risk-alert, potiki 'opportunity-seeking' usually younger, leaders who may be risk-takers, kaumātua 'elders' who are often risk-adverse and tohunga 'specialists'. One individual could embrace one or more of these values or roles. This paper essentially expands on earlier articles which have examined customary-based leadership in innovation and which focussed on two types-potiki and rangatira (Tapsell and Woods 2008b, 2010). A significant factor in this story is not only how four leadership values were important as reflective of cultural principles, but also how each worked together, hence kotahitanga of difference. Leaders within the core leadership team acknowledged the different styles and perspectives of each other. But more than that, these differences were seen as strengths. On the basis of acceptance of difference, multiple issues could be navigated from complementarily viewpoints. Additionally, opportunities to act were seen by some of the leaders that were not seen by other members of the leadership team. Opportunity recognition itself is a key plank in entrepreneurship studies and I return to this further below. For purposes of the current discussion, however, the team approach applied within Ngāti Whātua was essential as 
they progressed their enterprise aspirations.

Other writers (e.g., Foley 2008a, Peredo 2001, Peredo and Chrisman 2006,) have noted the salience of team-based leadership in indigenous entrepreneurship elsewhere and it is worthwhile to elaborate upon this idea to further orientate discussions in the case study. Team-based leadership is an approach that could be described as a kind of collective entrepreneurship (Anderson et al. 2006: 60, Frederick and Henry 2004, Kawharu et al. 2012, Schumpeter 1949, Tapsell and Woods 2008a, 2008b) that is essentially based on strong networks within and beyond a community. Joseph Schumpeter, a leading thinker in early entrepreneurship studies, recognised that entrepreneurship might not only operate through individuals, but also through a collective approach. He explained that entrepreneurship need not be embodied in "[...] a single physical person [and] may be and often is filled co-operatively" (Schumpeter 1949: 256). The kotahitanga of difference theme effectively builds upon this broad idea. Related to team leadership is the importance of social networks for entrepreneurs (Davidsson and Honig 2003, Foley 2008b, Jenssen 2001) and cases such as that of Ngāti Whātua also demonstrate the reliance on these networks within a culturally-accountable or kin-accountable context.

Yet, while collective or team-based entrepreneurship and history may be important, Foley (2008b) and Anderson et al. (2006: 60) also remind us of the individuality of indigenous entrepreneurship, groups and communities. There is no homogenised indigenous entrepreneurial "way", different from other forms of entrepreneurship. Some factors will be shared across cultures, others will not. Foley (2008b: 209-10) considered, for example, the almost total destructive effects of colonisation on social (and cultural) networks within Australian Aboriginal peoples and the consequent cultural, social and physical isolation of (many) entrepreneurs, who out of necessity, sought mentorship and support from non-indigenous peoples. In the cases Foley studied, the entrepreneurs did not have support or networks within their communities, which necessitated them to seek those things from outside in order to succeed. Their endeavours were also often geared towards personal or family-focussed goals rather than wider community advancement aspirations (Foley, 2008b). In contrast, in New Zealand and Hawaiian examples, community networks (and accountabilities) were present and important to entrepreneurs and yet colonisation also had devastating, but different, effects in those countries as well (Foley 2008b).

While there are vast differences between the three countries in experiences concerning their indigenous populations and the geographic spread and population concentration of the communities, a key point remains: history does impact on indigenous entrepreneurship, either negatively, positively or 
both. History provides an important socio-economic contextual backdrop to more fully understand entrepreneurship within indigenous communities today. How history impacts or affects contemporary enterprise can be measured, in terms of for whom and for what purpose enterprises were created (e.g., for individual, family or community ends). In terms of accountability ties, they may or may not be important, depending on the historical trajectory of indigenous entrepreneurs and their communities of origin. Thus, to summarise so far, cultural coding for entrepreneurship entails essential features for Ngāti Whātua which includes history; the guiding cultural values kotahitanga of difference; the mana/manaaki dynamic; accountability networks and duties; and team leadership.

Three final elements of broader entrepreneurship thinking need to be mentioned as well because they are equally salient to Ngāti Whătua. The first borrows from economist Ludwig Lachmann, who described entrepreneurship as a continuous process of combining and recombining resources (Lachman 1978, 1986; see also discussions in Chiles et al. 2007, Kawharu et al. 2012, Tapsell and Woods 2010). Essentially, the resources in Ngāti Whātua were: (i) the people/leaders, skills and values, (ii) land, (iii) finance and (iv) related to the first point about people, strategic partnerships. The second point returns to Schumpeter who described innovation effectively as new combinations (see discussion in Chiles et al. 2007, Kawharu et al. 2012, Tapsell and Woods 2008a, 2008b, 2010). The resources within Ngāti Whātua were brought together in different and new ways to enable transformation. This meant dipping into the cultural kete 'kit' of expertise and experience, and from that basis seeking additional expertise from outside the community as required. The third idea concerns opportunity recognition, which is another major feature of entrepreneurship theories (Roberts and Woods 2005). The basic argument is that entrepreneurs identify opportunities or better ways from the norm to create and develop new value resulting in improved social and/or economic outcomes. An economic slant on this idea emphasises how individuals seize an opportunity to transform markets through innovation (Schumpeter 1934). A social entrepreneurship view of opportunity recognition is concerned with the construction, evaluation and pursuit of opportunities for social change (Chell 2007, Roberts and Woods 2005) and as innovation that aims to create or nurture social value rather than economic wealth (Austin et al. 2006).

\section{RESEARCH METHODS}

Before discussing the details of the Railway Land story, I outline a few notes about this research and my place within it. Over the last 30 to 40 years, numerous academics have discussed the importance of locating researchers' 
positions in the research process (Angrosino 2005, Davies 2008, Headland et al. 1990, O'Connor 2004, Smith 1999), and especially as it relates to a researcher's own culture (Kuwayama 2003, Ohnuki-Tierney 1984, Smith 1999). Identifying a researcher's position acknowledges not only connections between researcher(s) and participants, but also situates the perspective from which material is interpreted, including the degree to which reflexivity (Davies 2008) of the researcher within the research process is understood. In my case, because of my genealogical (whakapapa) connections to Ngāti Whātua and my engagement within hapu affairs over a number of years, I was privileged to access empirical data through the views of the key people involved in the innovation. I had also previously undertaken research for the Ngāti Whātua o Ōrākei (community trust of Ōrākei) representative entities, which gave me further insights from a strategic operational level into the broader community aspirations as led by their elected leaders. In terms of specific connections, I had a close family connection to the community's late kaumātua 'elder', Hugh Kawharu, who led the Treaty claim and who was also a key member of the small group that oversaw the Railway Land venture. Many discussions between Hugh and myself outside the formal realms of tribal meetings took place over the years. This article is shaped by those discussions. The Railway Land story is also one told by two kaumātua, Te Puna Tumahai and Joe Hawke, and (now Judge) Chris McGuire, who were instrumental in Ngāti Whātua's growth, development and entrepreneurship. Also central to the narrative is Patrick Snedden, who had a leading role in progressing the Railway Land initiative, and who was also involved in the early stages of the Treaty claim. Each of their views emerged from kōrero or 'interviews' I have had with them since 2013, some 20 years after the Railway Land innovation began. In the case of Te Puna, we would also kôrero or talk about Ngāti Whātua matters outside the interview context, as for example at the Ōrākei marae complex 'ceremonial courtyard, meeting house and dining hall' during functions of one sort or another. These provided a wider, rounded perspective on hap $\bar{u}$ futures. In essence, the advantages of my background, the relationships already established and the confidence they had in me to treat their information appropriately are that I am able to offer a nuanced, "insider" (Headland et al. 1990) account of the innovation.

My perspective is not, however, so neatly positioned simply as an insider. I am, from genealogical and contracted working perspectives, also an outsider to the events, and a university researcher working on a Government-funded project. The insider/outsider dichotomy is not, therefore, completely helpful. Dwyer and Buckle (2009) and Smith (1999) describe another kind of positioning within an investigative space as "somewhere in between the two". That applies broadly to my circumstances. However, to elaborate further on 
that positionality descriptor, my role may be more accurately explained as an "included researcher" (Fig. 1), which in a Māori research context is based on whakapapa-informed principles and practice. Whakapapa in principle refers to a researcher's cultural and social identity, while whakapapa in practice begins with having privileged access to information because of insider connections and it then frames how the material is interpreted and located within a historical narrative of community identity. Key steps in the historical narrative developed through an "included researcher" enquiry can be summarised as:

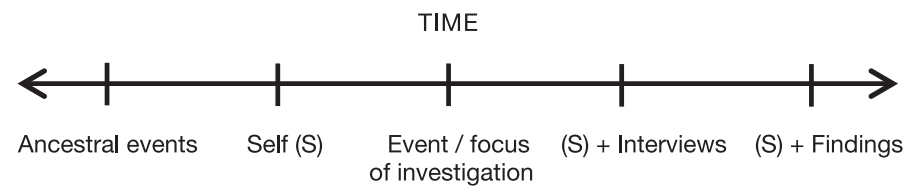

Figure 1. Historical narrative and "included researcher" location.

The "included researcher" position enables me to begin from a position of manaaki or inclusivity by virtue of my hapu membership, but also enables me to be one step removed and investigate from "outside of the action".

\section{ENTREPRENEURSHIP IN NGĀTI WHĀTUA}

In turning to explore the innovation within Ngāti Whātua, their starting point in terms of guiding principles, as outlined so far, is their history. Theirs has centrally been about their plight in securing their place within their ancestral landscape and affirming these values in the eyes of their community as well as others external to them: central and local governments and Auckland citizens. These were issues when the first government was established in Auckland in 1840 following Ngāti Whātua's invitation to the British to bring its government to their lands, and which have continued through to today. ${ }^{3}$ Achieving such ends may seem relatively straight-forward. However, a different picture is revealed when the community's key motivation over many decades has centred on confronting Crown and local government over land acquisition and loss. Ultimately, the community was reduced to owning a quarter acre $[0.1$ hectares $]$ - a cemetery at that. Their living narrative has then been about responses to setbacks and, fundamentally, acquiring and then re-securing ancestral land.

The years leading up to the Railway Land venture and the Treaty claim were critical in terms of entrepreneurship building blocks. As a first step, the creation and nurturing of accountability links between individuals (the leaders) and their community needed to take place. This was a clear, 
demarcated phase, totally unconnected to the specifics of the entrepreneurship in subsequent years, but entirely connected to the community. Essentially, leaders had to prove their worth to lead. In the process, the community was given the opportunity to accept, or to reject, this leadership. This was reciprocity in action and it was a central ingredient in creating the grounds for entrepreneurship to materialise in years to come.

Throughout the 1970s, three key people came to have roles within the Ngāti Whātua community in critical events that essentially set in train the way that Ngāti Whātua would organise themselves to confront challenges, both immediately in front of them and in the future. In 1978 the first board, called the Ngāti Whātua o Ōrākei Māori Trust Board, constituted by Section 4 of the Orakei Block (Vesting and Use) Act 1978, was established.

Before this occurred, a series of activities and events unfolded that became foundational to shaping Ngāti Whātua's existence and status in the eyes of Aucklanders and wider New Zealand. Essentially the community was provoked into a defensive position, brought about by a Government plan to turn a pristine open headland area bordering the community and marae into a new housing "suburb" for the wealthy. The land in question was arguably one of the most valuable areas of real estate in the country, but to Ngāti Whātua its economic value was not what made it important. It was their ancestral land.

The "defensive position" took the form of a protest occupation of the land for 506 days until 25th May 1978, known as the Bastion Point occupation. This occupation was led by Joe Hawke and others. Joe exercised a pivotal role, also representing a growing broader Māori resistance to the engines of modern colonisation and brought attention to the injustices to Māori regarding land. The occupation was a climax of previous efforts to "right wrongs" in relation to land (http://www.nzonscreen.com/title/bastion-point--the-untold-story-1999, Waitangi Tribunal 1987). Through Joe's leadership, the community's plight was laid out.

The "land issue" that lay simmering beneath the frustrations in the 1970s was not only in relation to the pristine headland that was occupied, but also to the acquisition of wider lands, including their former village which had been nestled in the bay below until 1951. In that year the last of the remaining lands that lay under their village were acquired. Residents of remaining homes strongly refused to leave. Many were, however, forcibly removed and relocated to the hill nearby, next to the headland "occupation" area. State houses were built on this hill and community members moved into them, now as tenants in Crown-owned houses and on Crown land (Kawharu 1975, 1989, Waitangi Tribunal 1987). This eviction was one of the most poignant of moments recalled by Te Puna and Joe as they remembered as youth the despair of their kaumätua including kuia 'elder women' at having to leave their homes and 
seeing their meeting house and homes burnt and destroyed. It is said amongst community members that someone from within the community deliberately burned the meeting house. That they were already being forced to leave was difficult enough, and the community did not want further insult to be added to the existing hurt by having outsiders take away their ancestral meeting house. Rather, it was thought, it was better to deal with the house themselves.

Also during the 1970s there were "offline" discussions, out of the public eye, between Ngāti Whātua elders, aided or driven by Hugh Kawharu on the one hand, and Government on the other hand. As reported elsewhere (e.g., Waitangi Tribunal 1987), several issues concerned the elders and Hugh, but the heart of these concerns was to restore tribal control over land and houses for Ngāti Whātua. They were similar arguments to those of Joe and others, but also different in specifics and in the solutions sought. In particular, Hugh and the elders sought "control" through a Trust entity that would bring the lands and houses into a unified administration under the customary authority of Ngāti Whātua. The land focus was restricted to a specific area, leaving aside, but also signalling to the Government, the issue of broader grievances relating to the wider area (including the former village that was destroyed, the marae and surrounding land) for a subsequent case, one that ultimately became the "Ōrākei claim" (Waitangi Tribunal 1987).

In the middle of the two channels of strong leadership was another-Te Puna Tumahai. He is closely related to Joe Hawke, but also worked closely with Hugh and the elders. He held a strategic middle ground, meaning that he could easily manoeuvre between family groups as a trusted relation. In time these connections and relationships provided a solid base of support, something that was essential in the field of tribal politics. When it came to holding a formal role as a trustee on the first elected Trust Board, the ground work in demonstrating accountability to the tribal community led towards $\mathrm{Te}$ Puna polling highest (Waitangi Tribunal 1987: 169). He was one of the longest serving members of the Trust Board and Deputy (to Hugh) for many years.

All three had different leadership approaches and were focussed on different, but also similar, issues. Joe, for example, was concerned to publically voice his concerns and raise the profile of issues, similar to other indigenous or minority movements around the world at the time. Hugh was concerned to find solutions, also according to customary protocols and kaumātua acceptance, and pressure the Government to accept them through negotiation and persuasion. And Te Puna was concerned to ensure respectful relationships were kept, support the new efforts for establishing a board, and support elders. Parallel pathways were undertaken within Ngāti Whātua, each opposing Government policy in the quest to resurrect the mana of Ngāti Whātua. 
While the leadership positions were clearly demarcated, it was this precise "mix" - kotahitanga of difference - that was a critical success factor of the entrepreneurship in relation to the Railway Land deal in the 1990s. At one end of the spectrum there was the outspoken, edgy, risk-taking and boundarypushing persona of Joe. It was a brave, fearless, leadership. At the other end of the spectrum was the moderate intellectual style of leadership of Hugh, and Te Puna maintained the important kin-connecting middle space, very similar to elder roles (Kawharu et al. 2013). The leadership styles were complementary, and they were borne out of resistance to the Crown and collaboration within the community. The difficult period of the 1970s essentially saw each of the key people demonstrate and develop their accountability to community members. By the 1990s, each undertook critical roles as trusted representatives for the community concerning the former railway lands.

\section{THE EVENTS: THE RAILWAY LAND INITIATIVE}

Hugh Kawharu (pers. comm.) described the Railway Land venture, which began with the purchase of 24.3 hectares of Auckland central business district land, as by far the most important commercial transaction that the $i w i$ had been involved in since European contact, which began some 160 years ago. Te Puna agreed, saying it was "the singular major issue, economically, for the Board and for Ngāti Whātua, ever" (Tumahai, pers. comm, 1 November 2013).

The events are as follows. Around 1991, Joe saw that the Government was about to dispose of surplus railway land. He was quick to alert them about Ngāti Whātua's interests in it. It helped too that he had a physical presence at the Railway Station. If the Government was going to be difficult, the theatrics of occupation were always an option. That is exactly what Joe did. He brought tutors and a training programme into the station. "We basically took over the Railway Station, we occupied the Railway Station. Others got the message. Everyone vacated. My issue was to occupy." (pers. comm, 6 June 2015). The 1970s Takaparawhau (Bastion Point) occupation was only "yesterday" and Joe knew what it could achieve. The Government also knew and they backed down from their idea at the time to retain the land (and not allow Ngāti Whātua to purchase it). It was understandable that Joe would do what he did. The land was reclaimed, it was a former fishing ground and waka 'canoes' were pulled in ashore nearby. "It is the moana [sea] of Ngāti Whātua" as Joe said (pers. comm, 6 June 2015).

At the same time as this first positioning, Joe, Hugh, Chris and Pat got together to scope out the next move. The Government had its own momentum to conclude its surplus railway land policy soon and it was, therefore, an urgent issue to address. Millions of dollars were also needed. In early 1992 the Government agreed to sell a portion of the railway land to Ngāti Whātua for $\$ 19$ million. By the end of that year, a deed of option was entered into 
and $\$ 45.5$ million was the then agreed price. ${ }^{4}$ Chris explained that this price was more than market value and more than any other offer on the table, but Ngāti Whātua were prepared to pay for it because of the opportunities they saw, and also the cultural and historic significance of the area to them (pers. comm., 28 March 2014). It was a critical opportunity to re-establish their connection in the central part of Tamaki in the eyes of their community and Auckland. A Treaty of Waitangi claim was considered as an avenue to pursue regarding "loss" in relation to the area. A concern about that option, however, was that the Government was moving fast in dealing with its surplus railway land policy and a claim could take too long. There would be no guarantee either that a claim would result in the land title going to Ngāti Whātua. The risks were, therefore, too great. Ngāti Whātua saw the opportunity and realised that they needed to act immediately, even if they did not know exactly what the next steps would entail.

Considerable efforts and time passed before any final sale and purchase was entered into. Delays occurred because at the same time a casino application process was underway. ${ }^{5}$ During this period of delay, the original Crown department with which Ngāti Whātua originally dealt became defunct and was replaced by another. Further delays occurred because the new department then tried to argue that there was no enforceable "deal". There was even the argument that the land was now worth considerably more, almost double the originally agreed upon purchase price, and furthermore, it should be paid for. Ngāti Whātua were shocked at this turn of events. Shocked also given that Ngāti Whātua had originally generously offered much land to the first New Zealand Government in 1840, enabling Auckland to be built; this fact seemed to count for nothing. The issue was simply about the honour of the Crown against this long historical backdrop. And of course, Ngāti Whātua had been in this back-foot situation only a few years earlier.

Hugh and the Ngāti Whātua lawyer Chris McGuire then put considerable tactical pressure on the Government, through letters and phones calls to senior Government officials and ministers, seeking a return to the original purchase price agreement. They were also armed with other supporting views (for example, external legal advice). In August 1996, the Crown relented to Ngāti Whātua pressure and agreed to sell at the non-inflated price. This was some four years after the original agreement. Persistence and patience were paramount.

While political and strategic issues took up the bulk of the time to just get an agreement to purchase, the other major issue of finding financial support was still burning. Ngāti Whātua urgently needed to find $\$ 45.5$ million to now buy the land. They had very little money and limited assets. A business partner was needed and they also needed bank support. A major question was who would be interested in partnering with a Māori group who had no track record in business generally, let alone in land or property development specifically. 
There were in fact many eager punters, or "tyre kickers" as Chris described them, but none had the credibility or commitment to follow through. One canvassed option involved partnering with a Hong Kong developer. The chair of the Ngāti Whātua Board at that time, respected elder Ruby Grey, argued that if the land would come back, she was prepared to wait 100 years. What she meant was that allowing the Hong Kong group to have the land virtually rent-free for 100 years was "ok" because the land would be secured by their development presence. Although the Hong Kong proposal fell through, it enabled Ngāti Whātua to fine-tune their ideas. Moreover, one hundred years would have been a very long time with no income from the land. Obtaining economic value from the land within a current lifetime became a central issue and the focus of the next step (Patrick Snedden, pers. comm, 15 April 2015).

Then came Magellan Ltd. After many discussions and negotiations both within the Ōrākei Māori Trust Board and between the Ngāti Whātua representatives and Magellan, Ngāti Whātua agreed to enter into a joint venture partnership with them. In essence this entailed spending money to improve the land, subdivide it and prepare the blocks for leasehold sale. Then, following the sales, Ngāti Whātua could be paid and they could then pay their bank. For its part, Magellan effectively enabled Ngāti Whātua to get the land (Chris McGuire, pers. comm., 28 March 2014). There were, however, major unknowns about who would be interested in buying the leasehold sections. Buying was slow. Stakes were high, risks were great because considerable money had already been spent in preparing the land for sale (for example, roads, street lighting, pavements and other landscaping) without knowing much about market interest. Ngāti Whātua also agreed to lend money to Magellan. Sections were bought, but not enough in the first critical stages. Difficulties were compounded by an "Asian crisis" which had resulted in their investment in New Zealand in property, such as for downtown office spaces and apartments, slowing considerably (Patrick Snedden, pers. comm., 15 April 2015). David Jones, a potential anchor tenant, also pulled out from investing. Then, as if things could not get worse, Magellan went into receivership (The New Zealand Herald, 2001). It was a major set-back as Ngāti Whātua lost millions of dollars on their bank loan and the money which had been loaned to Magellan. It was a major blow to a kin community which was on an economic precipice.

Once again, a significant challenge was how to confront these set-backs. Once again, the collective heads came together - as Chris described- "to problem solve". Many ideas were canvassed. One was that they sell some of their land to recover the debt, but that was not supported as Hugh explained, “... given the kind of perspective we have on things - 150 years - we don't think that's a very sensible way of thinking about our economic affairs. ${ }^{6}$ In 
the end, it was decided that the debt would be "handled", broadly measured against a long-term strategy of selling the leaseholds and recovering costs.

Despite this difficult first phase, a crucial fact was nevertheless the reality: Ngāti Whātua now had title to a significant land area. Eventually, all the leasehold titles were bought and the Ngāti Whātua Railway Land now has apartments, a convention centre, a health clinic, petrol stations, restaurants, many business blocks and other small businesses. In August 2011, the 15-year rent-free holiday which leaseholders had, came to an end. These businesses began paying the hapu ground rent annually, which now comprises a significant regular income. As Patrick described, the chance of Ngāti Whātua being able to reinfranchise itself within a generation is now very real (pers. comm., 15 April 2015). A lot of detail has been omitted, but the foregoing overview gives a sense of the challenges and outcomes. That Ngāti Whātua was able to pull off this major deal was, according to Te Puna and Hugh, not far short of a miracle. Patrick agreed (pers. comm., 15 April 2015) adding "That we pulled it off against all odds is phenomenal. There were big, big risks". The hap $\bar{u}$ had no experience in such major economic dealings. They had limited expertise, and there was considerable cost (Kawharu 2004: 80). There was also the rather important detail that they hardly had any money, nowhere near what was needed. Their security was their assets, which mainly consisted of housing stock recently returned from the Government as settlement of the Ōrākei claim. How then could a relatively poor kin community with no commercial experience make it all happen? Tens of millions of dollars were needed on the financial front (i.e., economic resources), but also considerable business sense, strategic planning and the right kind of cultural resources. The latter were essentially the values of mana/manaaki, kotahitanga of difference, and accountability. It was important to have the right mix of these economic, social and cultural "resources".

Returning to Lachmann $(1978,1986)$, who described entrepreneurship as a continuous process of combining and recombining resources, especially in new ways, we can use this general guide to consider the core resources of Ngāti Whātua and how they were combined and recombined to achieve their extraordinary outcome. These resources - people and their valuesfundamentally provided the cultural coding, along with finance and land that underpinned their enterprise.

COMBINING AND RECOMBINING RESOURCES AND CULTURAL CODING

Hugh and Te Puna both explained that a chief strategic resource was the Trust Board's lawyer, Chris McGuire. He was far more than a lawyer, as events would prove. He was centrally involved in negotiations and, where necessary, made vigorous representations to businesses, local or central 
government officials as a key member of the Ngāti Whātua team. He proposed pathways, ideas and tactics, and initiated and led discussions with Magellen. He also provided protection to Ngāti Whātua by sounding out and then dealing with opportunists who were eager to enter into partnerships with Ngāti Whātua to make a few dollars but with little regard for anything else (Chris McGuire, pers. comm, 28 March 2014). Patrick Snedden's financial expertise was also critical. Together, these tactical skills were key strategic resources, a kind of modern-day tohunga or specialist skillset that were brought into the hap $\bar{u}$, and combined with the rangatira, potiki and kaumātua leadership resources of Hugh, Joe and Te Puna, in entirely new ways that had not been seen before within the community. The leadership values celebrated a kotahitanga of difference. Imbedded within that was a commonality of purpose, and the value manaaki, which included the team's trust and respect of each other, cooperation, patience, and a focus on problem-solving. Openness and clear communication with the wider Trust Board, with whom all major issues were discussed, were also important. The Board were always briefed and supported the steps being taken. The basic principles were important to change the thinking of sceptics within the Board and to resolve any doubts. The Board guided the process and decisions, always by consensus, and following full discussion and debate. All of these things helped the leadership team to come to a position of strength or mana on an issue. They also built upon the underlying principle of hapu accountability or manaaki, where decisions were made with the community's future squarely in mind.

Securing the long-term, inter-generational future also was a central guiding philosophy. This vision meant securing land now for generations to come. The "future" planning had a very long-term horizon, some 150 years, much longer than most commercial businesses. It was something that Hugh was particularly keen to implement, especially in terms of what he and the collective leadership team could leave as an asset base for their descendants (mokopuna). In 150 years, everything on the land (i.e., buildings and infrastructure) would revert to Ngāti Whātua. Planning now for then and for intervening years, step by step, was important. This thinking gave a new level of meaning to manaakitanga considering people's needs inter-generationally, where profits of the Railway Land venture could be channelled into economic, social and cultural growth of the descendant community. Taken from these perspectives, the Railway Land venture was legacy-making.

While long-term, forward-thinking was central to the railway planning, history was also important as discussed at the beginning of this article. The "institutional" knowledge of hapu history, values and kinship dynamics, were carefully woven into the Railway Land plan as well. As Te Puna explained, 
he had been involved since the beginning, not only since the 1970s when the Board began, but also before that, as a hapū member growing up within the Ngāti Whātua network of whānau 'family' on ancestral land. The recent and longer-term history provided important guides for what is important politically, economically and culturally. The ultimate low point of the community in the 1950s triggered an extraordinary response of resilience of the part of all three hapu members. Both Joe and Te Puna were young and lived in the old village. Hugh and his mātua (father, uncles and aunts) were also affected by those events as Hugh commented to me in the 2000s; they shaped his sole focus of acquiring and reacquiring as much land as possible within Tamaki, within whatever legal means was necessary. This was to ensure that the deep loss suffered by Ngāti Whātua in the mid-20th century, when they were forcibly removed from their land, would never be repeated. With a solid economic foundation, they would flourish.

The historical guides of the 1950s, the 1970s and the colonial period before that, acted as reference points for the hapu leaders. They described leadership actions that were carried out (the "people" dimension) and they described resources that were important (the "land" dimension). Both of these things helped to contextualise the Railway Land venture within this whakapapa or genealogy of Ngāti Whātua affairs. Knowledge of the community's past was, therefore, vital in terms of understanding the cultural context and the relevance of history for shaping a path (Tumahai, pers. comm, 1 November 2013). History was also important from the point of view of the three Ngāti Whātua leaders themselves, who had first built trust with the hapu which then supported them in making key decisions on their behalf.

The "resources" that Lachmann refers to were principally, in Ngāti Whātua's case, the people. The skills provided by each were knitted together, and recombined. Other resources were of course, the finance and land, without which there was no "deal". It was the combination and recombination of all of these things within a team-led entrepreneurial context that created a template or matrix for success. There were plenty of difficulties and questions about matters of detail, but the ultimate goals of land title and income generation from it to then reinvest back into community socio-economic ends have been achieved.

$$
* * *
$$

The entrepreneurship undertaken within Ngāti Whātua occurred during the 1990s, but it was grounded in historical and cultural value contexts stemming from many years prior. The seeds for successful entrepreneurship were also sown well before and independent of the innovation. In that 
regard, demonstrating leadership and accountability within the community were essential. It began in the 1970s at a time when no one could have contemplated a venture of the complexity, scale and success of the Railway Land initiative.

Combined with the hapu leaders were individuals whose additional specialist skills contributed to the successes that unfolded. All worked together closely whilst celebrating their independent perspectives and approaches - kotahitanga of difference. They also operated according to the mana and manaaki dynamic, values that applied internally within the team, internally within the community, and externally with the Crown and private sector partners. Chris McGuire's description of "edges of leadership", that is, the risk-taking, novel, opportunity seeking and opportunity maximising stances taken by the leadership team, were strategic resources as well as being ultimate expressions of mana.

Particular questions facing the team were: how could the entrepreneurial venture: (a) address the historic loss of lands; (b) reconnect people and their ancestral lands; and (c) provide pathways for inter-generational cultural and economic transformation for the kin community. Their innovation brought together past, present and future foci, a kind of lived and living history.

At the beginning of this article, I began with an opening quote, "What do you make of this, partner?" While this was a rhetorical question Hugh put to a newspaper journalist about the Treaty claim, it was a sentiment that underpinned Ngāti Whātua's approach to both situations concerning the Treaty claim and the Railway Land development. It was about Ngāti Whātua presenting their case, again their mana, to the Crown, to then enable them to begin the process of acquiring the former railway land and leasing out sections.

In 2012 the Ngāti Whātua o Ōrākei CEO, Tiwana Tibble, remarked, "I am reminded of Sir Hugh Kawharu's observation when it was suggested the $h a p \bar{u}$ buy surplus Government-owned railway land for $\$ 40$ million. At that time he wryly commented the tribe didn't have 40c let alone $\$ 40$ million. And yet, here we are." (Kawharu 2001, Ngāti Whātua o Ōrākei 2012: 7). The "here we are" is seen in the $\$ 700+$ million asset base built in large part from the Railway Land innovation and grown under Tiwana's administration. ${ }^{7}$

To emerge out of a history of deprivation and anguish into a state of wealth and growing cultural confidence took something special. In the words of Hugh, working tirelessly for your people is where things begin, and it is where they end: Ko nga kurī purepure o Tamaki, e kore e ngaro i te pō; those wearing the spotted dog-skin cloak (leaders), are not lost in the night (never rest). 


\section{NOTES}

1. New Zealand's founding document, the Treaty of Waitangi, was between the British Crown, represented by Queen Victoria, and indigenous New Zealand Māori. It was signed in 1840 by hapu representatives and Britain's Crown representative, Captain William Hobson. The Queen remains New Zealand's formal Head of State, but governance today is through democratically elected members of parliament. The Queen's representative in New Zealand, the Governor General, is appointed on the recommendation of the Prime Minister. Herein the term "Crown" is used synonymously with the New Zealand "Government" and includes government departments (details on the New Zealand constitution can be found at https://gg.govt.nz/role/constofnz.htm ). As with other claims throughout New Zealand, that of Ngāti Whātua related to grievances concerning the lack of protection of rights and values guaranteed to Māori by the Treaty (see Kawharu 1989, Orange 2012, http://www.nzhistory.net.nz/politics/treaty-of-waitangi).

2. This article will be adapted for a book (in 2017) on New Zealand Māori entrepreneurship case studies by the author and Paul Tapsell.

3. Auckland is "home" to several other $i w i$ or tribal communities, all of whom have their own stories of association.

4. The early 1992 discussions for 13.8 hectares, including the Railway Station which was then costed at $\$ 19$ million, had crept up to $\$ 22.5$ million. The final land area was 24.3 hectares and was valued at the time of the agreement in December 1992 at $\$ 45.5$ million (Chris McGuire, personal files).

5. One of the applicants for a casino licence was a Māori-backed applicant, Auckland Casino Ltd., which was keen to establish a casino in the former Central Railway Station (American businessman, Donald Trump, was also interested in the venture and came to Auckland to meet the interested parties, and Ngāti Whātua).

6. Although Hugh spoke of this predicament to me directly, the quote came from a 2001 The New Zealand Herald article by Simon Collins.

7. Tiwana finished a 14-year tenure as CEO in August 2012. The Railway Land was valued at approximately half (The New Zealand Herald 2013).

\section{ACKNOWLEDGEMENTS}

I would like to acknowledge Jim Peters and the James Henare Māori Research Centre at the University of Auckland for support as I wrote this paper under the auspices of a Marsden Fund project. This article was also the culmination of efforts of key people. I would like to thank: Chris McGuire for his considerable commitment, feedback and help to me in writing this article; Te Puna (Danny) Tumahai for his patience and invaluable insights on a number of issues specifically relating to the Railway Land story and other hapu matters; Joe Hawke for his beautiful story-telling and perceptions; and Patrick Snedden for his clear "accounting" of events. Finally, what I owe to Hugh is more than I can say. Nō reira, e Pāpā, moe mai rā. 


\section{REFERENCES}

Anderson, Atholl, Judith Binney and Aroha Harris, 2014. Tangata Whenua: An Illustrated History. Auckand: Bridget Williams Books

Anderson, Robert and R. Giberson, 2004. Aboriginal entrepreneurship and economic development in Canada: Thoughts on current theory and practice. In C. Stiles and C. Galbraith (eds), Ethnic Entrepreneurship: Structure and Process. Amsterdam: Elsevier Science, pp. 141-70.

Anderson, Robert, Benson Honig and Ana Maria Peredo, 2006. Communities in the new economy: Where social entrepreneurship and indigenous entrepreneurship meet. In C. Steyaert and D. Hjorth (eds), Entrepreneurship as Social Change. Cheltenham, UK and Northhampton, MA, USA: Edward Elgar, pp. 56-78.

Anderson, Robert, Bob Kayseas, Leo Paul Dana and Kevin Hindle, 2004a. Indigenous land claims and economic development: The Canadian experience. American Indian Quarterly 28 (3): 634-48.

Anderson, Robert, Ana Maria Peredo, Craig Galbraith, Benson Honig and Leo Paul Dana, 2004b. Towards a theory of indigenous entrepreneurship. Entrepreneurship and Small Business 1 (1/2): 1-20.

Angrosino, M.V., 2005. Recontextualizing observation: Ethnography, pedagogy, and the prospects for a progressive political agenda. In N. K. Denzin and Y. S. Lincoln (eds), The Sage Handbook of Qualitative Research. Thousand Oaks, CA: Sage, pp. 729-45.

Austin, James, Howard Stevenson and Jane Wei-Skillern, 2006. Social and commercial entrepreneurship: Same, different or both? Entrepreneurship Theory and Practice 31 (1): 1-22.

Buck, Peter, 1950. The Coming of the Maori. Wellington: Whitcombe and Tombs.

Chell, E., 2007. Social enterprise and entrepreneurship. International Small Business Journal 25 (1): 5-26.

Chiles, Todd, Allen Bluedorn and Vishal Gupta, 2007. Beyond creative destruction and entrepreneurial discovery: A radical Austrian approach to entrepreneurship. Organization Studies 28 (4): 467-93.

Dana, Leo Paul, 2007 Toward a multidisciplinary definition of indigenous entrepreneurship. In L.P. Dana and R.B. Anderson (eds), International Handbook of Research on Indigenous Entrepreneurship. Cheltenham: Edward Elgar, pp. 3-7.

Dana, Leo Paul and Robert Anderson (eds), 2007. International Handbook of Research on Indigenous Entrepreneurship. Cheltenham: Edward Elgar.

Davidsson, Per and Benson Honig, 2003. The role of social and human capital among nascent entrepreneurs. Journal of Business Venturing 18 (3): 301-31.

Davies, Catherine, 2008. Reflexive Ethnography. A Guide to Researching Selves and Others. 2nd edition. Oxford: Routledge.

Dwyer, Sonya and Jennifer Buckle, 2009. The space between: On being an insideroutsider in qualitative research. International Journal of Qualitative Methods, 8 (1): 54-63.

Firth, Raymond, 1972. Economics of the New Zealand Maori. Wellington: A.R. Shearer, Government Printer. 
Foley, Dennis, 2008a. Indigenous (Australian) entrepreneurship? International Journal of Business and Globalisation 2 (4): 419-36.

2008b. Does culture and social capital impact on the networking attributes of indigenous entrepreneurs? Journal of Enterprising Communities: People and Places in the Global Economy 2 (3): 204-24.

Frederick, H. and Ella Henry, 2004. Innovation and entrepreneurship amongst Pākehā and Māori in New Zealand. In C. Stiles and C. Galbraith (eds), Ethnic Entrepreneurship: Structure and Process, International Research in Business Disciplines, Vol. 4. Amsterdam: Elsevier Science, pp. 115-40.

Headland, Thomas N., Kenneth L. Pike and Marvin Harris (eds), 1990. Emics and Etics: The Insider/Outsider Debate. Newbury Park, California: Sage Publications.

Henry, Ella, 2007. Kaupapa Māori entrepreneurship. In L.P. Dana and R. Anderson (eds), International Handbook of Research on Indigenous Entrepreneurship. Cheltenham: Edward Elgar, pp. 536-48.

Hindle, Kevin and Michele Lansdowne, 2005. Brave spirits on new paths: Toward a globally relevant paradigm of indigenous entrepreneurship research. Journal of Small Business and Entrepreneurship. Special Issue on Indigenous Entrepreneurship 18 (2): 131-41.

International Labour Organisation, n.d. "Who are the Indigenous and Tribal Peoples?" Available at www.ilo.org/global/topics/indigenous-tribal/WCMS_503321/lang-en/index.htm, accessed 1 July 2016.

Jenssen, Jan Inger, 2001. Social networks, resources and entrepreneurship. International Journal of Entrepreneurship and Innovation 2 (2): 103-9.

Kawharu, I.H., 1975. Orakei: A Ngati Whatua Community. Wellington: NZCER. 1989. Orakei. In I.H. Kawharu (ed.), Waitangi: Maori and Pakeha Perspectives of the Treaty of Waitangi. Auckland: Oxford University Press. 2001. Land and Identity in Tamaki. A Ngāti Whātua perspective. Hillary Lecture, a public lecture given at the Auckland War Memorial Museum. Available at: https://www.aucklandmuseum.com/CMSPages/GetAzureFile.aspx\%5C?path=/ aucklandmuseum/media/main/maori_culture/events_lectures/land_and_identity lecture notes.pdf, accessed 5 January 2015.

Kawharu, I.H. (ed.), 1989. Waitangi: Maori and Pakeha Perspectives of the Treaty of Waitangi. Auckland: Oxford University Press.

Kawharu, Merata (ed.), 2014. Maranga Mai! Te Reo and Marae in Crisis? Auckland: Auckland University Press.

Kawharu, Merata, 2004. "Sustainable Development, Partnerships and Mana Whenua". In I. Carter, D. Craig and S. Matthewman (eds), Almighty Auckland? Palmerston North: Dunmore Press, pp.75-88.

Kawharu, Merata, Paul Tapsell and Christine Woods, 2012. Maori entrepreneurial behaviour: Lachmannian insights. Journal of Australian Indigenous Issues 15 (4): 62-75.

2013. Resistance and Challenge: The Shaping of Indigenous Entrepreneurship, a Maori Context. Paper presented to Australian and New Zealand Academy of Management Conference, Hobart, December 2013. 
Kuwayama, Takami, 2003. 'Natives' as dialogic partners. Some thoughts on native anthropology. Anthropology Today 19 (1): 8-13.

Lachmann, Ludwig, 1978. Capital and Its Structure. Kansas: Sheed Andrews and McMeel Inc.

1986. The Market as an Economic Process. Oxford: Basil Blackwell.

Lindsay, Noel, 2005. Toward a cultural model of indigenous entrepreneurial attitude. Academy of Marketing Science 2005 (5): 1-15.

Mahuika, Apirana, 1992. Leadership: Inherited and achieved. In M. King (ed.), Te Ao Hurihuri: Aspects of Māoritanga. Auckland: Reed Books, pp. 42-63.

McGuire, C., personal files.

Ngāti Whātua Ōrākei, 2012. Annual Report. Auckland: Ngāti Whātua o Ōrākei.

O'Connor, P., 2004. The conditionality of status: Experience based reflections on the insider/outsider issue. Australian Geographer 35 (2): 169-76.

Ohnuki-Tierney, Emiko. 1984. "Native" anthropologists. American Ethnologist 11 (3): 584-86.

Orange, Claudia, 2012. Treaty of Waitangi. Te Ara - the Encyclopedia of New Zealand. Available at http://www.TeAra.govt.nz/en/treaty-of-waitangi, accessed 16 November 2016.

Peredo, Ana Maria, 2001. Communal Enterprises, Sustainable Development and the alleviation of Poverty in Rural Andean Communities. Unpublished Ph.D. thesis, University of Calgary.

Peredo, Ana Maria and James Chrisman, 2006. Toward a theory of community-based enterprise. Academy of Management Review 31 (2): 309-28.

Petrie, Hazel, 2006. Chiefs of Industry. Māori Tribal Enterprise in Early Colonial New Zealand. Auckand: Auckland University Press.

Roberts, Dave and Christine Woods, 2005. Changing the world on a shoestring: The concept of social entrepreneurship. University of Auckland Business Review Autumn: 45-51.

Robinson, Kevin, 2014. Motutī Road: At the end of the road, just the beginning? In M. Kawharu (ed.), Maranga Mai! Te Reo and Marae in Crisis? Auckland: Auckland University Press, pp. 97-102.

Schumpeter, Joseph, 1934. The Theory of Economic Development. Cambridge MA: Harvard University Press.

Schumpeter, Joseph A., 1949. Economic theory and entrepreneurial history. In The Research Centre in Entrepreneurial History (ed.), Change and the Entrepreneur: Postulates and Patterns for Entrepreneurial History. The Research Centre in Entrepreneurial History. Cambridge MA: Harvard University Press, pp. 63-84.

Smith, Linda Tuhiwai, 1999. Decolonizing Methodologies: Research and Indigenous Peoples. New York: Zed Books.

Tapsell, Paul, 2014. Tribal marae: Crisis? What crisis? In M. Kawharu (ed.), Maranga Mai! Te Reo and Marae in Crisis? Auckland: University Press, pp. 35-64.

Tapsell, Paul and Christine Woods, 2008a. A spiral of innovation framework for social entrepreneurship: Social innovation at the generational divide in an indigenous context. Emergence: Complexity and Organisation 10 (3): 25-34. 
2008b. Potikitanga: Indigenous entrepreneurship in a Maori context. Journal of Enterprising Communities 2 (3): 192-203.

2010. Social entrepreneurship and innovation: Self-organisation in an indigenous context. Entrepreneurship and Regional Development 10 (5): 1-22.

The New Zealand Herald, 2001. Bastion Point Proposal Divides Maori. Article by Simon Collins, 20 March. Available at http://www.nzherald.co.nz/nz/news/article. cfm?c_id=1\&objectid=222600, accessed 12 May 2015.

2013. Ngati Whatua Chief Leaves on High Note. Article by Anne Gibson, 15 August. Available at http://m.nzherald.co.nz/business/news/article.cfm?c id=3\&objectid=10827040, accessed 10 January 2014.

United Nations, n.d. Indigenous Peoples, Indigenous Voices Factsheet. Available at http://www.un.org/esa/socdev/unpfii/documents/5session_factsheet1.pdf, accessed 1 July 2016.

Walker, Ranginui, 1990. Ka Whawhai Tonu Matou. Struggle Without End. Auckland: Penguin.

Waitangi Tribunal, 1987. Report of the Waitangi Tribunal on the Orakei Claim. Wellington: The Tribunal.

\title{
Other Web links
}

https://gg.govt.nz/role/constofnz.htm

http://www.nzhistory.net.nz/politics/treaty-of-waitangi

http://www.nzonscreen.com/title/bastion-point---the-untold-story-1999

\begin{abstract}
Innovation and entrepreneurial endeavour by Māori communities is increasingly capturing the attention of academics and wider society, but like indigenous entrepreneurship studies more generally, Māori entrepreneurship is still a relatively new field of study. A gap or an opportunity in both cases is to critically examine the application of culture in entrepreneurship. Culture can of course mean many things to many people. Theoretical insights concerning culture in indigenous entrepreneurship will develop as case studies are investigated, and factors unique or different to each are understood. In this article, therefore, and in contributing towards theory development, I explore one particular innovation, modelled by a frame called cultural coding for entrepreneurship. Cultural coding identifies and examines essential features for the successes that unfolded within the Auckland-located kin community Ngāti Whātua as they pursued an extraordinary entrepreneurial endeavour: acquiring and then securing a large area of central business district land (the Railway Land, including the former central Auckland Railway Station) in New Zealand's largest city. Case study analysis is further aided by insights stemming from renowned economists Ludwig Lachman and Joseph Schumpeter concerning combining and recombining resources in new ways, and the related idea of "opportunity recognition". The resources were principally the people and their values, but they also included land and finance, without which there was no enterprise. This article stems from research undertaken within
\end{abstract}


the author's community from a researcher position that is located between the insider and outsider dichotomies, but which is more aligned to a nuanced Māori research positionality described in this research as a whakapapa or genealogically-informed "included researcher".

Keywords: Indigenous entrepreneurship, New Zealand Māori, cultural coding, "included researcher", Ngāti Whātua, Treaty of Waitangi.

\section{CITATION AND AUTHOR CONTACT DETAILS}

Kawharu, ${ }^{1}$ Merata, 2016. Indigenous Entrepreneurship: Cultural Coding and the Transformation of Ngāti Whātua in New Zealand. Journal of the Polynesian Society 125(4): 359-382. DOI: http://dx.doi.org/10.15286/jps.125.4.359-382

${ }^{1}$ Correspondence: Te Tumu, School of Maori, Pacific \& Indigenous Studies, University of Otago, P.O. Box 56, Dunedin, New Zealand. Email: Merata.kawharu@, otago.ac.nz 